\title{
15 Challenges for the law of the sea in South East Asia
}

\author{
Resolving current controversies \\ and addressing horizon threats
}

David Letts and Donald R. Rothwell

\subsection{Introduction}

The law of the sea in South East Asia is currently facing many challenges. These challenges arise not so much from the law itself but from the consequences of the law of the sea for the region and how South East Asian States have responded to the law. As has been demonstrated throughout this book, ${ }^{1}$ South East Asian States have been beneficiaries and strong supporters of the law of the sea, as framed around the 1982 United Nations Convention on the Law of the Sea (LOSC). ${ }^{2}$ This is unsurprising, given that the two largest archipelagic States, Indonesia and the Philippines, are located within the region. However, while the LOSC has conferred many benefits upon South East Asian States it has also created new challenges. The most self-evident of these has been the need to negotiate an array of maritime boundaries in a tightly congested and contested maritime domain. Another consequence has been the greater entitlements of coastal States to the living and non-living natural resources of the seas and oceans within South East Asia. This has created a higher level of economic and food security for some States but has also resulted in some competition for these resources and associated management issues. In this regard another factor is Taiwan, its unique status and its needs and interests as a fishing entity. A final factor creating challenges for implementing the law of the sea in the region is that the LOSC confirms the status of South East Asian waters as ones in which certain freedoms of navigation apply. These freedoms extend from the waters of the Straits of Malacca and Singapore, where transit passage rights apply, to archipelagic sea lanes in Indonesia and the Philippines to the general freedoms of navigation for the ships of all States in exercising innocent passage and high seas freedoms in both the exclusive economic zone (EEZ) and the high seas. These navigational rights and freedoms are the lifeblood of trade and commerce throughout South East Asia and have been pivotal in the growth of regional economies.

1 See Rothwell and Letts in Chapter 1, and Stephens in Chapter 9.

2 United Nations Convention on the Law of the Sea, 10 December 1982, 1833 UNTS 397 [hereafter LOSC]. 
This chapter assesses the challenges confronting the law of the sea in South East Asia by first considering current and known controversies and how the law of the sea has responded to and is shaping those controversies. Consideration will then move to an assessment of known, assumed and potential horizon threats for the law of the sea in South East Asia.

\subsection{Resolving current controversies}

\subsubsection{Territovial and mavitime claims}

Reflecting upon the dynamics of South East Asia's maritime domain noted above, a characteristic of the region is how unresolved territorial disputes have implications for the law of the sea which create an impediment for the resolution of maritime boundaries and related maritime issues. There is no greater example of this impasse than in the South China Sea, especially the claims and counter-claims made to territory in the Spratly Islands group. A failure to resolve these territorial issues will only further escalate existing nationalistic tensions throughout the region, which, in many instances, may result in a hardening of resolve to not make concessions. To that end, a critical issue is attaining a precise understanding of the maritime entitlements of the disputed features. In this regard, the South China Sea arbitration ${ }^{3}$ is instructive in that while the LOSC Annex VII Tribunal had no jurisdiction to resolve the territorial disputes, it was competent to pronounce upon the entitlements of the various maritime features that it was assessing, ranging from Article 121 islands, to Article 121 (3) rocks, to Article 13 low-tide elevations. While China has consistently rejected the authority of the South China Sea arbitration, it remains the most authoritative decision of any international court or tribunal on this matter and is the only decision of its type with respect to the South China Sea. The South China Sea arbitration is a legitimate basis upon which to characterise the various maritime features in the region, which may have the effect of neutralising aspects of the territorial disputes if a feature is found to be a low-tide elevation incapable of generating any independent maritime zone.

A resolution of the status of these maritime features is important for resolving maritime boundaries throughout greater South East Asia. While there is a developing track record with respect to the negotiation of maritime boundaries, ${ }^{4}$ more boundaries remain in need of resolution in order to bring greater certainty to South East Asia's maritime domain. Other factors are also at play in this regard, including the assessment of Article 76 outer continental shelf claims before the Commission on the Limits of the Continental Shelf (CLCS), some

3 In the Matter of an Arbitration before An Arbitral Tribunal Constituted Under Annex VII to the 1982 United Nations Convention on the Law of the Sea between The Republic of the Philippines and the People's Republic of China, PCA Case no 2013-19, Award of 12 July 2016 [hereafter South China Sea arbitration].

4 See the discussion by Schofield in Chapter 3 . 


\section{David Letts and Donald R. Rothwell}

of which may be significantly delayed as a result not only of the backlog in the Commission's work but also because of the Commission's refusal to consider applications where territorial disputes exist. In this regard, it needs to be recalled that LOSC Article 83 permits States to enter into 'provisional arrangements of a practical nature', 5 which may present some States with an opportunity to move ahead with the interim settlement of continental shelf boundaries pending resolution of CLCS submissions.

\subsubsection{Marine resources}

Whilst the LOSC has generated substantial maritime entitlements in South East Asia, it has also resulted in increased resource conflict over living and non-living resources. The high level of dependence within the region upon fisheries and other marine living resources as a food source has created increased competition for those limited resources resulting in significant challenges for EEZ resource management, including the policing of illegal, unreported and unregulated (IUU) fishers. This issue has increasingly gained prominence within the Association of South East Asian Nations (ASEAN), and in 2017 the ASEAN Regional Forum adopted a statement seeking to address regional IUU fishing challenges. ${ }^{6}$ However, while some South East Asian States have given this issue increased attention, ${ }^{7}$ responses have been variable. ${ }^{8}$ In addressing this challenge, increased acceptance and rigorous implementation of the global, regional and sub-regional fisheries management frameworks is one foundation. New policy responses to meet this challenge are also essential, ${ }^{9}$ some of which will require greater collaboration between neighbouring States akin to measures adopted in Europe and the South West Pacific. Ultimately, there is a need for a shared sense of regional fisheries stewardship and diminished competition.

With respect to South East Asian marine oil and gas reserves, a regional characteristic is that vast reserves are largely untapped due to ongoing maritime boundary disputes and claims and counter-claims over the South China Sea. It has been estimated that the South China Sea holds about 190 trillion cubic feet of natural gas and 11 billion barrels of oil in proved and probable reserves, ${ }^{10}$

5 LOSC, Article 83(3).

6 ASEAN Regional Forum Statement on Cooperation to Prevent, Deter and Eliminate Illegal, Unreported, and Unregulated Fishing, 7 August 2017, available online at www.asean2017.ph/ wp-content/uploads/8.ARF-Statement-on-Cooperation-to-Prevent-Deter-and-EliminateIUU-Fishing-_Adopted.pdf

7 This has particularly been the case in Indonesia, see M. Tennesen, 'Blowing Up Illegal Fishing Boats Helps Indonesian Fishers', Scientific American, 6 August 2018, available online at www. scientificamerican.com/article/blowing-up-illegal-fishing-boats-helps-indonesian-fishers/

8 See M.J. Williams, 'Will New Multilateral Arrangements Help Southeast Asian States Solve Illegal Fishing?’, (2013) 35 Contemporary Southeast Asia pp. 258-283.

9 See the discussion by Tsirbas in Chapter 13.

10 US Energy Information Administration, 'South China Sea', 7 February 2013, available online at www.eia.gov/beta/international/regions-topics.php?RegionTopicID=SCS 
while in 2010 the US Geological Survey estimated an additional undiscovered 160 trillion cubic feet of natural gas and 12 billion barrels of oil. ${ }^{11}$ With these estimates, it is unsurprising that the region has a record of maritime clashes over oil and gas exploration and development which have only served to heighten regional tensions. ${ }^{12}$ Nevertheless, there are examples of South East Asian States working cooperatively on offshore oil and gas ventures within joint development frameworks as envisaged by the LOSC. ${ }^{13}$ China, as the largest regional State and the one with the greatest energy needs, has begun to explore cooperative bilateral arrangements with Brunei and the Philippines. ${ }^{14}$ Joint development of offshore oil and gas has a long-standing track record and can with political will and robust mechanisms bring about mutually beneficial results for all parties. ${ }^{15}$ In the face of unresolved EEZ and continental shelf boundaries, joint development provides a way forward, ${ }^{16}$ though the development of such a regime in the South China Sea poses complex legal and geopolitical issues. ${ }^{17}$

\subsubsection{Marine environment}

South East Asia has a complex marine environment which is facing multiple challenges. ${ }^{18}$ Some of these, such as climate change, are global in nature, while others exist as a result of individual State actions that arise from land reclama-

11 US Geological Survey, 'Assessment of Undiscovered Oil and Gas Resources of Southeast Asia, 2010' Fact Sheet 2010-3015, June 2010, available online at http://pubs.usgs.gov/ fs $/ 2010 / 3015 / \mathrm{pdf} / \mathrm{FS} 10-3015 / \mathrm{pdf}$

12 Numerous clashes have occurred between China and Vietnam with respect to offshore oil and gas exploration off the Vietnamese coast and in the South China Sea; see, for example, L. Murdoch, 'South China Sea: Vietnam Accuses China of dragging Oil Rig into its Waters' The Sydney Morning Herald, 21 January 2016, available online at www.smh.com.au/world/southchina-sea-vietnam-accuses-china-of-dragging-oil-rig-into-its-waters-20160121-gmafrl.html; R. Jennings, 'Vietnam Faces New Oil Dispute With China After Beijing Cuts Visit Short', Voice of America, 26 June 2017, available online at www.voanews.com/a/vietnam-faces-new-oildispute-with-china-after-beijing-cuts-visit-short/3915859.html

13 This includes the Malaysia-Thailand Joint Authority which operates in the Gulf of Thailand; for details see www.mtja.org/home.php.

14 M.A Kuo, 'The Geopolitics of Oil and Gas in the South China Sea', The Diplomat, 12 December 2018, available online at http://the diplomat.com/2018/12/the-geopolitics-of-oiland-gas-in-the-south-china-sea/

15 For a discussion of some of the relevant processes, see C. Schofield, 'Defining Areas for Joint Development in Disputed Waters' in S. Wu and N. Hong (eds), Recent Developments in the South China Sea Dispute: The Prospects for a Joint Development Regime, London: Routledge, 2014, pp. 78-98.

16 See the collection of papers on this issue in R.C. Beckman, I. Townsend-Gault and C. Schofield (eds), Beyond Territorial Disputes in the South China Sea: Legal Frameworks for the Joint Development of Hydrocarbon Resources, Cheltenham: Edward Elgar, 2013.

17 See R. Emmers, 'China's Influence in the South China Sea and the Failure of Joint Development' in E. Goh (ed), Rising China's Influence in Developing Asia, Oxford: Oxford University Press, 2016, pp. 155-173.

18 See the discussion by Warner in Chapter 5 and Scott in Chapter 6. 
tion and the building of artificial islands. To that end, one of the challenges for the region has been reconciling sustainable development with the legitimate economic and development aspirations of South East Asian peoples. In this respect, the complexity of the regional marine environment needs to be acknowledged. Indonesia and the Philippines as vast archipelagic States encompassing thousands of islands enjoy sovereignty over a maritime domain that is predominantly within their national limits. Singapore's maritime domain, on the other hand, is shared with Indonesia and Malaysia with the consequence that transnational marine environmental issues have implications for its bilateral relations. ${ }^{19}$ South East Asian marine environmental issues have been given greater prominence as a result of China's artificial island building and land reclamation in the South China Sea. Whilst China's conduct was the subject of detailed assessment in the South China Sea arbitration, ${ }^{20}$ notwithstanding the tribunal's findings that China's activities were the cause of significant environmental impact in breach of the LOSC, China did not cease its island building activities. More regional initiatives are therefore required to address challenges faced by the South East Asian marine environment, including the impacts of climate change. The launch in 2018 of the 'Marine Environment Protection for Southeast Asian Seas (MEPSEAS) Project' under the auspices of ASEAN and the International Maritime Organization $(\mathrm{IMO})^{21}$ is, in that regard, a welcome step; however, there remains a need for distinctive regional initiatives to deal with ship-sourced and land-based marine pollution, and the impacts of landbased pollution.

\subsubsection{Navigational vights and freedoms}

One of the highest profile ongoing law of the sea issues confronting the region relates to the freedom of navigation in the South China Sea. In that respect, it needs to be observed that while there have previously been disagreements regarding the exercise of navigational rights and freedoms throughout South East Asian straits and archipelagos ${ }^{22}$ various forms of mutual accommodation have been reached to resolve those issues within the LOSC framework. In the

19 As highlighted by the issues arising from Singapore's land reclamation in its relations with Malaysia in Land Reclamation by Singapore in and around the Straits of Johor (Malaysia v Singapore) (Provisional Measures) (2003) 126 ILR 487.

20 South China Sea arbitration, [815-993]; see the detailed assessment in T. Stephens, 'The Collateral Damage from China's 'Great Wall of Sand': The Environmental Dimensions of the South China Sea Case' (2016) 34 Australian Year Book of International Law pp. 41-52.

21 International Maritime Organisation 'MEPSEAS Project Launched to Protect South-East Asia Marine Environment', 26 June 2018, available online at www.imo.org/en/MediaCentre/ PressBriefings/Pages/11-MEPSEASLAUNCH.aspx

22 See, for example, I. Shearer, 'Navigation Issues in the Asian Pacific Region' in J. Crawford and D.R. Rothwell (eds), The Law of the Sea in the Asian Pacific Region, Dordrecht: Martinus Nijhoff, 1995, pp. 199-222; and generally D.R. Rothwell and S. Bateman (eds), Navigational Rights and Freedoms and the New Law of the Sea, The Hague: Martinus Nijhoff, 2000. 
South China Sea, however, an ongoing source of tension between China and the United States relates to the exercise of navigation rights by US warships and military vessels, especially whilst engaged in 'freedom of navigation' operations (FONOPS). ${ }^{23}$ In this respect, it needs to be recalled that the LOSC's navigation regimes apply to all ships, whether commercial or government vessels (including warships) ${ }^{24}$ and in some cases these regimes also include overflight by aircraft. The South China Sea and more generally South East Asia can also be considered unique in the sense that all of the LOSC's four navigation regimes are present in what is a relatively confined geographic region. ${ }^{25}$ Commercial ships navigating in these waters should be aware that there are different views and practices among States regarding each of these navigation regimes. First, there are maritime areas where the applicability of a particular navigation regime is disputed due to a territorial or maritime dispute, leading to differences of opinion regarding when a vessel is required to undertake 'innocent passage' in the relevant territorial sea or whether more permissive passage rights can be exercised. Second, the legality of various activities associated with navigation is subject to different interpretations, including disagreement as to whether a violation of local law and regulations of the coastal State necessarily renders the passage as non-innocent. Third, with the increased use of unmanned autonomous vessels for commercial purposes, there is a question regarding the navigational entitlement of such vessels.

Notwithstanding these ongoing disagreements regarding the application and interpretation of the LOSC, it needs to be emphasised that to date there has not been any significant interference with commercial shipping in the South China Sea. Any such interference would clearly be counter-productive to the freedom of trade in the region and possibly have global ramifications, making it unlikely that any State would contemplate direct interference with passage of a commercial vessel in the ordinary course of events. China, in particular, would be mindful of the implications arising from any impact upon the freedom of navigation of commercial shipping for its Belt and Road Initiative.

\subsubsection{Status of the South China Sea arbitration}

In addition to the matters noted above, lingering issues arise from the 2016 South China Sea arbitration. China's insistence that it will not recognise the award as the outcome of the arbitration does not change the fact that a legitimately constituted LOSC Annex VII tribunal handed down the award which is 'final and without appeal'. ${ }^{26}$ The Philippines as the applicant in the proceedings

23 See the discussion by Stephens and Quadrio in Chapter 10.

24 LOSC, Articles 17-26, 38, 52, 87.

25 Those being LOSC, Article 17 (innocent passage), Article 38 (transit passage), Article 53 (archipelagic sea lanes passage), and Article 87 (high seas freedom of navigation); see also Nasu in Chapter 11.

26 LOSC, Annex VII, Art 11; which does provide for an appeal process if the parties had so agreed; however, no agreement to that effect was reached in this instance. 


\section{8}

is the State with both the moral, legal and political authority to seek to have the award enforced; however, it has not sought to do so. In this respect, it needs to be recalled that President Rodrigo Duterte took office on 1 July 2016, just weeks before the tribunal handed down the award and accordingly his administration inherited proceedings commenced by his predecessor, Benigno Aquino III. President Duterte has also consistently taken a low-key approach towards the 2016 award, preferring to advance bilateral relations between China and the Philippines, and in November 2018 a joint statement was issued following a visit by Chinese President Xi Jinping to Manila, stating that

Both sides agree to exercise self-restraint in the conduct of activities in the South China Sea that would complicate or escalate disputes and affect peace and stability. Both sides also note the importance of confidence-building measures to increase mutual trust and confidence. ${ }^{27}$

South China Sea issues between China and the Philippines would therefore appear to have been settled through diplomatic manoeuvring and attempts to enforce the award appear to be remote. That does not mean that the award's finding with respect to China's assertion of the Nine-Dash Line will be ignored, as there are other States within South East Asia and more broadly who accept the award and its finding that there is no basis in the law of the sea for the Nine-Dash Line. While China's insistence upon recognition of the Nine-Dash Line will more than likely continue, it can be expected that irrespective of the Philippines' position China will continue to experience opposition in its efforts to seek to enforce the claim. More than likely however, the status of the Nine-Dash Line will become mingled with China's efforts to assert other aspects of its South China Sea maritime claims offshore its territories.

\subsubsection{Dispute resolution}

A notable feature of South East Asia and the law of the sea is the number of cases that have been taken before international courts and tribunals in recent years. This has resulted in a range of formal dispute resolution mechanisms having been utilised, ranging from the International Court of Justice ${ }^{28}$ to the International Tribunal for the Law of the Sea ${ }^{29}$; LOSC Annex VII Arbitration ${ }^{30}$; and, on the margins of South East Asia, the LOSC Annex V Compulsory

27 'Joint statement of the Philippines and China', Philippines Star, 21 November 2018, available online at www.philstar.com/headlines/2018/11/21/1870517/full-text-joint-statement-philippinesand-china\#SAPYh3SltThKvajt.99

28 Sovereignty over Pedra Branca/Pulau Batu Puteh, Middle Rocks and South Ledge (Malaysia/ Singapore) [2008] ICJ Reps 12.

29 Land Reclamation by Singapore in and around the Straits of Johor (Malaysia v Singapore) (Provisional Measures) (2003) 126 ILR 487.

30 As occurred in the South China Sea arbitration. 
Conciliation between Timor-Leste and Australia. ${ }^{31}$ South East Asian States have therefore become familiar with a range of formal mechanisms to resolve their law of the sea disputes, which has resulted in confidence-building with respect to the capacity of those mechanisms to bring about a successful resolution of the dispute when diplomatic means have not succeeded. In that regard, it is notable that even following its rejection of both the 2015 decision on jurisdiction ${ }^{32}$ and the subsequent 2016 decision on the merits in the South China Sea arbitration, China has continued to work with ASEAN members to finalise the proposed 'Code of Conduct' (CoC) for the South China Sea. There continue to be great expectations associated with the CoC; however, its negotiation has been exceptionally slow, and doubts remain regarding its capacity to bring about a resolution of South China Sea disputes and associated tensions, including whether the instrument will be legally binding. ${ }^{33}$

With the exception of the $\mathrm{CoC}$, there is no other apparent diplomatic initiative on the table for the resolution of maritime and associated territorial disputes in the region. The apparent impasse over the South China Sea suggests the time is ripe for innovative diplomatic solutions, raising the prospect of a South China Sea Commission. A 15-member Commission with a mandate to facilitate mediation, conciliation and ultimately arbitration of the disputes would provide both an informal and formal third-party mechanism capable of dealing with the disputes at both a bilateral and regional level. Under this model, each of the six South China Sea claimants would appoint a Commission member, with the remaining nine members appointed from outside the region. The Commission's reach could extend to both land and maritime disputes, including islands, rocks and other small maritime features such as reefs and shoals. Its mandate could also extend to determining maritime entitlements and maritime boundaries consistently with the LOSC, with the exception of the continental shelf beyond 200 $\mathrm{nm}$ which falls within the remit of the CLCS. Commission members would be diplomats and jurists with expertise in territorial and maritime disputes, assisted by a staff of permanent technical experts including geographers, historians, hydrographers and marine scientists. The Commission could be established by a negotiated treaty framework, whereby each State gives its consent.

31 In the Matter of the Maritime Boundary between Timor-Leste and Australia before a Conciliation Commission Constituted under Annex V to the 1982 United Nations Convention on the Law of the Sea between the Democratic Republic of Timor-Leste and the Commonwealth of Australia, PCA Case no 2016-10, Report and Recommendations of the Compulsory Conciliation Commission between Timor-Leste and Australia on the Timor Sea of 9 May 2018.

32 In the Matter of an Arbitration before An Arbitral Tribunal Constituted Under Annex VII to the 1982 United Nations Convention on the Law of the Sea between The Republic of the Philippines and the People's Republic of China, PCA Case no 2013-19, Award on Jurisdiction and Admissibility of 29 October 2015.

33 See, for example, M.J. Valencia, 'A South China Sea Code of Conduct? Don't Get Your Hopes Up', The Diplomat, 30 May 2017, available online at https://thediplomat.com/2017/05/ a-south-china-sea-code-of-conduct-dont-get-your-hopes-up/ 
A South China Sea Commission would be entirely consistent with Article 33 of the Charter of the United Nations ${ }^{34}$ which encourages regional solutions to disputes and would add to the already extensive range of peaceful means and methods of dispute resolution that are available ${ }^{35}$ However, unlike those bodies which are mainly located in Europe, a South China Sea Commission would be located within South East Asia. Commission members could predominantly come from within the region. Contentious issues of consent would have been addressed by each individual State having signed and agreed to support the Commission. Creative legal solutions could be found through the flexibility of mediation or conciliation, with legally binding arbitration a last resort. Such an approach could be a regional solution for a regional problem.

\subsection{Addressing horizon threats}

Trying to predict how future maritime threats in South East Asia will arise, and subsequently be addressed, is an inherently difficult process that involves a mixture of considered speculation combined with calculated assessment of likely future events and behaviour. Nevertheless, undertaking a brief evaluation of a number of scenarios that may eventuate in the future provides a way of rounding out the discussion that has been provided in this book while leaving scope for future research and discourse in subsequent years.

\subsubsection{Excessive maritime claims}

Resolution of maritime claims that do not conform to the legal regimes set out in the LOSC is one area that could realistically be progressed in South East Asia. However, to achieve this, a fundamental re-assessment by States of their publicly articulated position in relation to these non-conforming claims would be needed, and there would also have to be recognition by States that it is clearly in their national interest to do so. If this does not occur, then the prospect for additional unilateral declarations by States that do not accord with the LOSC, such as the Air Defence Identification Zone declared by China in November $2013,{ }^{36}$ will remain at least a credible possibility. There is, of course, the possibility that a 'snowball' effect of claims that do not conform to the LOSC could become the norm in South East Asia, with States perhaps taking cognisance of those excessive claims that already exist ${ }^{37}$ as well as China's response to the South China Sea arbitration. ${ }^{38}$ It is hoped that the future does not take that

34 Charter of the United Nations, 26 June 1945, 1 UNTS XVI.

35 See the discussion by Klein in Chapter 14.

36 See the explanatory statement at Embassy of the People's Republic of China in the United States of America, 'Defense Ministry Spokesman on China's Air Defense Identification Zone', 4 December 2013, available online at www.china-embassy.org/eng/zt/dhfksbq2/

37 See the discussion by Rothwell in Chapter 2 and Tim Stephens in Chapter 9.

38 See the discussion by Klein in Chapter 14. 
path, however, consolidated action will be required from regional States, perhaps with ASEAN involvement, to advocate LOSC compliance including responding to compliance fractures that may start to appear. In this regard, the region will continue to face the impact of climate change and sea level rise, which will have consequences for both straight and archipelagic baselines that have been drawn to and from islands, low-tide elevations and reefs that may become completely submerged. This will raise further tensions within the region regarding the status of baselines, the maritime claims upon which they are based, and concluded maritime boundaries. For Indonesia and the Philippines, there may even be a need to reassess their entitlements as archipelagic States. Regional solutions to this problem, within a LOSC framework, would be desirable.

\subsubsection{Maritime security and the presence of non-State actors}

The continued presence, and influence, of non-State actors in South East Asia is a source of concern that will require ongoing vigilance for the foreseeable future. Employment of a 'maritime militia' by China is destined to continue as a feature of responses to perceived threats to Chinese maritime interests in the region, and perhaps expanding to other areas in close proximity to the Chinese coastline. ${ }^{39}$ The concept of 'hybridity' that accompanies the employment of the maritime militia obfuscates the ability of other States to classify militia vessels as being representatives of the State, and clouds the maritime picture with a degree of uncertainty. However, the presence of maritime militia is not the only way in which non-State actors are likely to influence the region in the future. The activities of a number of terrorist groups, most notably Abu Sayyaf in the southern Philippines, are likely to remain a factor that requires ongoing commitment in order to defeat threats to regional maritime security. ${ }^{40}$ Although the Philippines government has taken decisive steps to neutralise the threat posed by Abu Sayyaf in the archipelagic mainland, there remains an ongoing threat of piracy $^{41}$ and other maritime crimes, especially in the Sulu and Celebes Seas. Elsewhere in the region, the actions of authorities in Indonesia have seen a drop in reported maritime security incidents with 'low level opportunistic thefts ${ }^{42}$ being the most common type of incident although both Indonesia and the eastern part of Malaysia have experienced hostage-taking or kidnapping. ${ }^{43}$ The use of maritime routes for people smuggling and outflows of refugees both within

39 See the discussion by McLaughlin in Chapter 8 .

40 See the discussion by Letts in Chapter 4.

41 The International Chamber of Commerce's International Maritime Bureau has stated that reports of piracy in the Philippines have decreased from 22 in 2017 to ten in 2018: International Maritime Bureau, 'IMB Piracy Report 2018: Attacks Multiply in the Gulf of Guinea', 16 January 2019, available online at www.icc-ccs.org/index.php/1259-imb-piracyreport-2018-attacks-multiply-in-the-gulf-of-guinea

42 Ibid.

43 Ibid. 
South East Asia, and in an attempt to reach peripheral States such as Australia, will also likely continue as an important security concern.

\subsubsection{Responding to maritime security threats: small-scale use of force and cooperative measures}

Responding to maritime security threats will likely involve a combination of traditional 'on-water' maritime law enforcement response options as well as the increased use of intelligence gathering by regional States and organisations that support maritime security. The former has a well-established legal framework in which operations occur, involving a combination of international law and domestic implementing legislation, and jurisprudential principles governing the use of force in maritime law enforcement operations. ${ }^{44}$ The latter is presently in an embryonic stage in South East Asia, although encouraging signs regarding regional cooperation between States are emerging. It has been noted that ASEAN's networks for the exchange of information are complex, comprising both informal and formal channels, and many of these are also built on 'longterm interpersonal and interagency relationships of trust'. ${ }^{25}$ Measures such as the establishment of ReCAAP's Information Sharing Centre and the creation of Singapore's Information Fusion Centre provide an example of how intelligence can be collected and shared among regional States without undue concern, and the bolstering of the capacity of these existing bodies will be necessary to ensure that cooperation among regional States continues to grow.

\subsubsection{Militarisation and military operations}

In terms of the South China Sea littoral States, an ongoing upgrade of military capabilities has been underway for a number of years raising questions whether a regional 'arms race' is taking place, with suggestions that replacement of obsolete weapons systems, and those that are unable to be deployed at all, feature high on the upgrade agenda. ${ }^{46}$ In terms of maritime capacity-building, there has reportedly been an increase in spending on '...maritime aviation, mobile anti-ship missile systems and maritime surveillance'. ${ }^{47}$ It is expected that this

44 These principles have been derived from the often quoted cases of The I'm Alone (Canada/ United States of America) 3 RIAA 1609, The Red Crusader (1962) 35 ILR 485, and MV Saiga No. 2 (Saint Vincent and The Grenadines v Guinea) (1999) ITLOS case No. 2.

45 See J. Coyne and I. Kfir, 'Improving Maritime Security in the Asia-Pacific', The Strategist, 16 January 2019, available online at www.aspistrategist.org.au/improving-maritimesecurity-in-the-asia-pacific/?utm_medium =email\&utm_campaign=Daily $\% 20$ The $\% 20$ Strategist\&utm_content=Daily\%20The\%20Strategist+CID_b5165a9decc4a4ee978610cd299 bl07b\&utm_source=CampaignMonitor\&utm_term=Improving\%20maritime\%20security $\% 20$ in $\% 20$ the $\% 20$ AsiaPacific

46 F. Heiduk, 'Is Southeast Asia Really in an Arms Race?', East Asia Forum, 21 February 2018, available online at www.eastasiaforum.org/2018/02/21/is-southeast-asia-really-in-an-arms-race/

47 Ibid. 
trend of modernisation and spending on military capability will continue. It is questionable whether military spending in the region is a response to China's growing military capability. ${ }^{48}$ Certainly, China's maritime capabilities have been enhanced in recent years with the shift in focus that is resulting in China's PLA-N becoming a 'blue-water' navy as evidenced through a number of naval task force deployments well beyond the immediate environs of the Chinese mainland. There are no signs that China's global maritime ambitions will diminish, and the vessel building programme that began in the early 2000s has been accelerated under the current Chinese leadership. ${ }^{49}$ An increase in naval operations within the region, by both littoral States and extra-regional States, will inevitably heighten tensions and place a further strain on the law of the sea.

\subsubsection{Impact of foreign aid and investment}

Foreign aid and investment will continue to flow into South East Asia through a variety of mechanisms. Some of this aid and investment will be through vast infrastructure projects, such as the Chinese Belt and Road Initiative which will have implications for the development of new ports, ${ }^{50}$ while other elements will comprise security assistance in the way of military equipment sales, training and support. Aid provided as a result of responses to natural disasters and tragic events, such as occurred when flight MH370 disappeared in 2014, will continue to be delivered as needed throughout the region. There are risks associated with any influx of foreign aid and investment which must be guarded against, both from the perspective of the donor and the recipient, with perhaps the most dangerous risk for recipient States being an inability to repay foreign loans that are tied to large infrastructure projects. ${ }^{51}$

\subsubsection{Resource disputes}

Disputes over harvesting the rich resources that exist in South East Asia's maritime spaces will remain a constant factor for the foreseeable future. There are ongoing challenges associated with exploiting the marine living and non-living resources in the region, in a highly charged environment where early resolution

48 S. Wu, 'What's Behind Southeast Asia's High Military Spending?', East Asia Forum, 25 May 2018, available online at www.eastasiaforum.org/2018/05/25/whats-behind-southeast-zasias-highmilitary-spending/

49 'With Ships and Missiles, China is Ready to Challenge US in the Pacific', SBS News, 29 August 2018, available online at www.sbs.com.au/news/with-ships-and-missiles-china-is-ready-tochallenge-us-in-the-pacific

50 See discussion regarding the Belt and Road Initiative by Tan in Chapter 12.

51 This has resulted in the so-called phenomena of 'debt trap diplomacy', which China has sought to respond to by way of a 2018 Measure for the Administration of Foreign Aid; see Laura Zhou, 'Debt-Trap Allegations Push China to Tighten Reins on Foreign Aid Programme' South China Morning Post, 14 November 2018, available online at www.scmp.com/news/china/diplomacy/ article/2173235/debt-trap-allegations-push-china-tighten-reins-foreign-aid 


\section{David Letts and Donald R. Rothwell}

of the region's maritime sovereignty disputes is not likely. Whilst there will be increased pressure for sustainable fishing practices to be widely adopted throughout the region, it is clear that this cannot occur to the detriment of other environmental concerns. ${ }^{52}$ Regional oil and gas production and exploration will need to increase as current known reserves dwindle. It is in the interests of States to investigate the scope for cooperative resource exploration activities, especially in the resource-rich South China Sea, notwithstanding that these activities would likely take place in waters where sovereignty is contested. Lessons need to be learned from unilateral resource exploration and development such as that which occurred in May 2014 when the Chinese oil rig HYSY 981 started operating in Vietnamese-claimed waters. ${ }^{53}$ The security and safety of submarine cables and pipelines is an often neglected aspect of resource management that will warrant close attention in the near future. Recognising this issue, the International Law Association has established a Committee to assess the adequacy of the existing international legal framework governing submarine cables and pipelines but this Committee is currently in its infancy with its first interim report not due until $2020 .{ }^{54}$ As far as South East Asia is concerned, the security of submarine cables and pipelines is an issue that has fundamental importance for the region's resource exploitation and management due to the direct linkages between these assets and economic prosperity.

\subsubsection{Marine scientific research}

Undertaking relevant marine scientific research in the region will have increased importance as pressures on resource management continue to build. However, one of the complicating factors that accompanies marine scientific research is the difference in opinion among States regarding precisely which research activities fit within the authority of the coastal State through the application of the EEZ regime. ${ }^{55}$ While on its face, it appears that the LOSC clearly provides that jurisdiction over marine scientific research in the EEZ rests with the coastal State, where the EEZ itself is contested or where States (such as the United States) claim that their research activities do not fit within the ambit of marine scientific research, the issue becomes problematic. ${ }^{56}$ These differences in opinion have the

52 See, for example, the discussion by Warner in Chapter 5 in relation to the impact of mangrove clearance undertaken (in part) to support the establishment of prawn and fish farms and Tsirbas, Chapter 13, in relation to the parlous state of the South China Sea fishery.

53 M. Green et al., 'Counter-Coercion Series: China-Vietnam Oil Rig Standoff', Asia Maritime Transparency Initiative, 12 June 2017, available online at https://amti.csis.org/counter-cooil-rig-standoff/

54 Proposal for establishment of a new ILA Committee on Submarine Cables and Pipelines under international law, available at www.ila-hq.org/index.php/committees.

55 See LOSC, Article 56.

56 The debate over the difference between marine scientific research and military marine scientific research or data collection has existed since the introduction of the EEZ regime in the LOSC; see for example, S. Bateman, 'Hydrographic Surveying in the EEZ: Differences and Overlaps 
potential to increase tension in the region as States seek to assert what they see as their rights to undertake scientific research (however defined) in the region's maritime spaces.

\subsubsection{Autonomous vessels}

The potential use of autonomous vessels throughout South East Asia is on the horizon. The technology is being tested in a number of locations throughout the world, and China is among those States that is investing heavily in automated vessels. ${ }^{57}$ The United States is also exploring the opportunities available from automated and unmanned vessels, with its main focus, at least initially, on military uses. For example, the United States Navy is developing the Sea Hunter Anti-Submarine Warfare (ASW) Continuous Trail Unmanned Vessel (ACTUV) which is reportedly able to travel for thousands of kilometres without any crew member onboard. ${ }^{58}$ Opportunities to use autonomous vessels for commercial, military and law enforcement purposes will expand in the near future, and these developments will fundamentally alter the way in which maritime activity occurs in the region. The deployment and/or use of vessels that do not have a crew onboard, extending as far as being provided with berthing assistance by autonomous tug boats, represents a seismic shift in the way that maritime operations are undertaken. However, this potential also raises a number of important legal issues regarding how existing legal instruments, such as the LOSC, are able to cope with the change as none of the these instruments were agreed at a time when automation was a viable option.

\subsubsection{United States presence/withdrawal from South East Asia}

A vexed question arises over the future of the United States and its forward deployed military forces in South East Asia. At his inauguration, President Trump announced that 'America First' would be the 'new vision' for the United States. Subsequently, the Trump Administration initiated a 'Free and Open Indo-Pacific' (FOIP) policy which represents a difference in focus from the 'pivot' to South East Asia that was prompted by the Obama Administration. ${ }^{59}$ However, what the practical effect of each of these policies has actually been

with Marine Scientific Research', (2005) 29 Marine Policy pp. 163-174; and R. Pedrozo, 'Military Activities in the Exclusive Economic Zone: East Asia Focus', (2014) 90 International Law Studies pp. 514-543.

57 See R. Jennings, 'China is Developing Ships to Cover the Globe Without Captains', Forbes, 14 March 2018, available online at www.forbes.com/sites/ralphjennings/2018/03/14/ china-is-developing-a-fleet-of-high-tech-ships-with-no-captains/\#f392cfd49be4

58 Defense Advanced Research Projects Agency, "ACTUV “Sea Hunter" Prototype Transitions to Office of Naval Research for Further Development', 30 January 2018, available online at www. darpa.mil/news-events/2018-01-30a

59 Barack Obama, 'Remarks By President Obama to the Australian Parliament', 17 November 2011, available online at http://obamawhitehouse.archives.gov/the-press-office/2011/11/17/ 
remains a topic of debate. Some have stated that the Obama 'pivot' had little real consequence, ${ }^{60}$ while others have opined that after two years of the Trump Administration, the FOIP was only just beginning to take shape. ${ }^{61}$ The obvious difference between the 'pivot' and FOIP is the way in which the relationship between the United States and China is envisaged. Under the pivot, direct confrontation with China was to be avoided while under FOIP the opposite is true. ${ }^{62}$ While political agendas regularly change, the impact of the United States implementing FOIP throughout the range of political, military and economic engagements that it has in South East Asia is yet to be fully assessed. One thing that does seem clear, however, is that regional States should prepare for a rollercoaster ride between China and the United States as both adjust their posture for future influence in the region. In that regard, whether the Trump Presidency extends beyond 2020 into a second term will be critical for implementation and the legacy of the FOIP.

\subsubsection{Foreign naval engagement in South East Asia}

Military presence in South East Asia is dominated by the United States and China and this situation is not likely to alter in the near future. Russia, India, Japan, South Korea and Australia all also play a prominent role in the region to varying degrees. ${ }^{63}$ However, other States are also showing an increased level of regional interest, as evidenced by the announcement from the British Defence Secretary that the United Kingdom would seek to build a military base in South East Asia within the next few years. ${ }^{64}$ Unsurprisingly, the announcement sparked mixed reactions. Chinese sources were reported as stating that the United Kingdom was acting at the behest of Washington and being 'provocative' by aligning with the hardened US approach towards Beijing. ${ }^{65}$ However, it was also reported that the news of the planned UK base would be welcomed by key US allies in the region who '...have been concerned about Washington's reluctance to take a leadership role to challenge Beijing's assertiveness in the South China Sea dis-

remarks-president-obama-australian-parliament; in which it was stated, 'The United States is a Pacific power, and we are here to stay'.

60 M. Green, 'The Legacy of Obama's "Pivot" to Asia', Foreign Policy, 3 September 2016, available online at https://foreignpolicy.com/2016/09/03/the-legacy-of-obamas-pivot-to-asia/

61 I. Storey and M. Cook, 'The Trump Administration and Southeast Asia: America's Asia Policy Crystalizes', (2018) ISEAS - Yusof Ishak Institute Perspective Issue No. 77, available at www. iseas.edu.sg/images/pdf/ISEAS_Perspective_2018_77@50.pdf

62 Ibid.

63 All of these States are included among the 15 countries that have the largest military budgets (2017 data); see D. Brown, 'The 15 Countries with the Highest Military Budgets in 2017', Business Insider Australia, 3 May 2018, available online at www.businessinsider.com.au/ highest-military-budgets-countries-2018-5? r=US\&IR=T

64 'Britain's Planned Naval Base in Southeast Asia seen as 'Muscle-Flexing' Against China', South China Morning Post, 1 January 2019, available online at www.scmp.com/news/china/military/ article/2180293/britains-planned-naval-base-southeast-asia-seen-muscle-flexing

65 Ibid. 
putes' ${ }^{66}$ The United Kingdom also indicated on several occasions in 2017 and 2018 that it was prepared to send an aircraft carrier through the South China Sea, including with a regional partner such as Australia. ${ }^{67}$

Existing defence alliances involving ASEAN States and external States are not likely to diminish in the near future. While it could be considered that some of these alliances, such as the Five Power Defence Arrangements (FPDA) between Malaysia, Singapore, the United Kingdom, New Zealand and Australia have little contemporary relevance, they will nevertheless remain in force and may even expand in scope if perceived regional threats begin to materialise. ${ }^{68}$ A further consideration arises from reports in May 2018 that President Trump sought options for United States troop reductions in South Korea, with both Japan and South Korea 'unnerved' at this prospect. ${ }^{69}$ Whether any future United States military reduction in South East Asia would also include a reduced naval presence is yet to be seen, but the indicators that can be gleaned from the number of FONOPS conducted by the United States Navy since President Trump's inauguration would seem to point to at least maintaining the status quo.

\subsection{Concluding remarks}

South East Asia's maritime environs are a fascinating mix of threat and opportunity, risk and reward, playground and source of tension as well as being home to rich resources and a large and growing population. The region presents a complex geopolitical picture that is punctuated by competing maritime sovereignty claims and a variety of maritime security concerns. Terrorist threats in the region were recognised at the 2018 ASEAN/Australia meeting in Sydney, where a Memorandum of Understanding was signed to address a variety of actions that can be undertaken to counter international terrorism, including that which manifests itself in the region's maritime environs. ${ }^{70}$ Other security threats, ranging from small-scale use of force to maritime crime and piracy, are also a constant source of concern. Yet, despite the challenges that exist, the vast majority of

66 Ibid. The report cited Australia, Japan and Vietnam as being examples of allies who would welcome the news of the future UK base.

67 S. Carrell, 'South China Sea: UK Could Send Aircraft Carrier to Back Australian Vessels', The Guardian, 21 July 2018, available online at www.theguardian.com/world/2018/jul/21/ south-china-sea-uk-could-send-aircraft-carrier-to-back-australian-vessels

68 See P. Parameswaran, 'Joint Military Exercise Highlights Five Power Defense Agreements', The Diplomat, 17 October 2018, available online at https://thediplomat.com/2018/10/ joint-military-exercise-highlights-five-power-defense-agreements/

69 C. Sang-Hun and M. Rich, 'Trump's Talk of U.S. Troop Cuts Unnerves South Korea and Japan', New York Times, 4 May 2018, available online at www.nytimes.com/2018/05/04/world/asia/ south-korea-troop-withdrawal-united-states.html

70 Memorandum of Understanding between the Association of Southeast Asian Nations and the Government of Australia to Counter International Terrorism, 17 March 2018 available online at http://setnas-asean.id/vendor/webarq/admin-lte/plugins/elfinder/files/KS\%20Eksternal/ ASEAN-Australia\%20MoU\%20on\%20International\%20Terrorism.pdf 


\section{David Letts and Donald R. Rothwell}

maritime activity that occurs in South East Asia does so in an environment that is relatively benign. Maritime trade flows through the region, commercial and military activity largely takes place without incident and the people of the region - for the most part - are able to live their lives in relative peace. But for this situation to continue the challenges and issues identified in this book will need to be seriously and comprehensively addressed by all States and other actors who possess an interest in the region's continued peace and prosperity, and to that end the law of the sea will be pivotal. 